$\begin{array}{rr}\text { JURNAL } & \text { Volume } 13, \text { Nomor } 1, \text { Januari } 2017 \\ \text { FIT(1)PATOLOGI } & \text { Halaman } 17-25 \\ \text { I N D O N E S I } & \text { DOI: } 10.14692 / \text { jfi.13.1. } 17-25\end{array}$

\title{
Mekanisme Pengendalian Penyakit Busuk Batang Jeruk oleh Khamir, Kitosan, Cendawan Mikoriza Arbuskular, dan Bakteri Simbiotiknya
}

\section{Control Mechanism of Citrus Stem Rot Disease by Yeast, Chitosan, Arbuscular Myrcorrhizal Fungi and Its Symbiotic Bacteria}

\author{
Hagia Sophia Khairani, Meity Suradji Sinaga*, Kikin Hamzah Mutaqin \\ Institut Pertanian Bogor, Bogor 16680
}

\begin{abstract}
ABSTRAK
Produktivitas tanaman jeruk seringkali dibatasi oleh penyakit tanaman. Di Indonesia, penyakit busuk batang yang disebabkan oleh Botryodiplodia theobromae menjadi penyakit penting yang menyebabkan tanaman jeruk mati meranggas. Penelitian dilakukan untuk mempelajari mekanisme pengendalian $B$. theobromae oleh khamir, cendawan mikoriza arbuskular (CMA), bakteri simbiotik CMA dan kitosan. Uji in vitro dilakukan untuk mengevaluasi mekanisme antibiosis, hiperparasitisme, produksi senyawa volatil, dan produksi enzim kitinase. Percobaan dilanjutkan dengan pengujian in planta terhadap khamir, CMA, bakteri simbiotik CMA terpilih, dan kitosan baik secara tunggal maupun kombinasi. Percobaan disusun dalam rancangan acak lengkap dengan 3 ulangan. Peubah yang diamati ialah periode laten, insidensi dan keparahan penyakit, laju infeksi, area under disease progress curve (AUDPC), tingkat asosiasi CMA, dan kandungan fenol total. Hasil uji in vitro menunjukkan bahwa khamir mempunyai aktivitas hiperparasitisme pada $B$. theobromae dengan afinitas 26 sel per hifa, memproduksi senyawa volatil dengan tingkat hambatan relatif (THR) $29.1 \%$, dan memproduksi enzim kitinase. Isolat bakteri simbiotik CMA terbaik menunjukkan mekanisme antibiosis dengan THR 42.9\% dan memproduksi senyawa volatil dengan THR $26.7 \%$. Isolat ini memiliki homologi $98 \%$ dengan Bacillus subtilis asal Vietnam. Perlakuan khamir + CMA + kitosan memperlambat periode laten dan menekan insidensi penyakit. Perlakuan tunggal CMA dan kombinasi khamir + CMA menekan keparahan penyakit, laju infeksi, dan nilai AUDPC. Aplikasi khamir + CMA menunjukkan tingkat asosiasi CMA dan peningkatan kandungan fenol total paling tinggi. Berdasarkan hasil penelitian ini, perlakuan tunggal CMA dan khamir + CMA direkomendasikan dalam pengendalian penyakit busuk batang jeruk.
\end{abstract}

Kata kunci: antibiosis, Botryodiplodia theobromae, hiperparasitisme, kitinase

\begin{abstract}
Plant diseases become an important constraint on citrus production. Stem rot disease caused by Botryodiplodia theobromae is a major disease on citrus in Indonesia. This study was aimed to evaluate the mechanism of yeast, arbuscular mychorrhiza fungi (AMF), symbiotic bacteria of AMF and chitosan in controlling stem rot disease. In vitro study was performed to evaluate the mechanism of antibiosis, hyperparasitism, production of volatile compounds, and production of chitinase enzyme. The experiment was continued by in planta assays using yeast, AMF, symbiotic bacteria of AMF, and chitosan either singly or in combination. The experiments were performed using completely randomized

*Alamat penulis korespondensi: Departemen Proteksi Tanaman, Fakultas Pertanian, Institut Pertanian Bogor. Jalan Kamper Kampus IPB Darmaga Bogor 16680.

Tel: 0251-8629364, Faks: 0251-8629362, Surel: mssinaga@yahoo.com
\end{abstract}


design with 3 replications. Disease progress were observed based on its latent period, AUDPC, infection rate, AMF association rate, and total phenol content. In vitro studies indicated that the yeasts showed hyperparasitism to $B$. theobromae with affinity of 26 cells per hyphae, produced volatile compounds with relative resistance level (RRL) $29.1 \%$, and produced chitinase. Selected symbiotic bacteria from AMF showed antibiosis with RRL $42.9 \%$, production of volatile compounds with RRL $26.7 \%$, and has 98\% homology with Bacillus subtilis from Vietnam. Application of yeast + AMF + chitosan delayed disease latent period and suppressed disease incidence. Single AMF and combination of yeast + AMF suppressed disease severity, infection rate, and AUDPC. Application of yeast + AMF showed highest association level of AMF and total phenol content. Therefore, the application of AMF and yeast + AMF is recommended in controlling citrus stem rot disease.

Key words: antibiosis, Botryodiplodia theobromae, chitinase, hyperparasitism

\section{PENDAHULUAN}

Jeruk merupakan buah unggulan di Indonesia yang produktivitasnya seringkali dibatasi oleh penyakit tanaman. Salamiah et al. (2008) dan Sinaga et al. (2009) melaporkan bahwa beberapa kebun di sentra produksi jeruk di Indonesia mengalami busuk batang gumosis dan mati meranggas yang disebabkan oleh Botryodiplodia theobromae sehingga menyebabkan penurunan produktivitas jeruk hingga 53.9\%. Patogen ini memiliki kisaran inang lebih dari 280 spesies tanaman dan menyebabkan gejala nekrosis batang, diikuti dengan gumosis, busuk batang, mati pucuk, dan mati meranggas (Adeniyi et al. 2016).

Jeruk umumnya dibudidayakan melalui perbanyakan secara okulasi. Selama ini, kultivar jeruk yang digunakan untuk batang bawah ialah Javansche citroen (JC) yang dilaporkan mulai tidak resisten terhadap penyebab penyakit busuk batang (Muhammad et al. 2003). Selain Trichoderma spp. dan Gliocladium spp., agens hayati khamir dan cendawan mikoriza arbuskular (CMA) dapat dijadikan komponen pengendalian penyakit tanaman. Kitosan yang merupakan suatu biopolimer juga dilaporkan mampu mengendalikan patogen penyakit seperti cendawan, bakteri, dan virus (Hadrami et al. 2010).

Pengendalian penyakit tanaman oleh agens hayati dan kitosan dapat terjadi melalui mekanisme: kompetisi, hiperparasitisme, dan memicu tanaman untuk memproduksi enzim kitinase (Hartati et al. 2014). Bakhtiar (2013) melaporkan bahwa CMA dapat meningkatkan kemampuan tanaman dalam menyerap air dan hara, memicu produksi fitoaleksin dan berbagai enzim pertahanan tanaman, dan berasosiasi dengan bakteri nonpatogen. Algam et al. (2010) menyatakan bahwa selain dapat menghambat pertumbuhan patogen, kitosan juga dapat meningkatkan ketahanan tanaman.

Potensi khamir, CMA dan bakteri simbiotik CMA, serta kitosan sudah banyak dievaluasi. Namun, informasi tentang mekanismenya mengendalikan $B$. theobromae pada tanaman jeruk belum banyak dilaporkan. Berkaitan dengan hal-hal tersebut, dilakukan studi yang bertujuan untuk mengevaluasi mekanisme pengendalian penyakit busuk batang jeruk oleh khamir, CMA, bakteri simbiotik CMA, dan kitosan.

\section{BAHAN DAN METODE}

\section{Penyiapan Isolat Patogen, Agens Hayati, dan Kitosan}

Isolat uji $B$. theobromae asal Garut (BT Grt) merupakan koleksi Laboratorium Mikologi Tumbuhan, Fakultas Pertanian, IPB. Isolat diremajakan pada medium agaragar dekstrosa kentang (ADK) dan agar-agar air (AA). Morfologi B. theobromae diamati berdasarkan pada perubahan warna koloni, karakter pertumbuhan, hifa, konidium, dan piknidium menggunakan mikroskop majemuk. Gejala infeksi penyakit busuk batang diamati pada tanaman yang diinokulasi $B$. theobromae di dalam rumah kaca. 
Khamir dengan kode isolat YP diperoleh dari koleksi Klinik Tanaman, Fakultas Pertanian, IPB. Isolat diremajakan pada medium ADK dan diinkubasi selama 48 jam. Isolat CMA diperoleh dalam bentuk produk komersial butiran siap pakai. Bakteri simbiotik CMA diperoleh dari inkubasi $0.5 \mathrm{~g} \mathrm{CMA} \mathrm{pada}$ medium trypticase soya agar (TSA) selama 24 jam. Isolat bakteri yang diperoleh diseleksi kemampuan antagonismenya secara in vitro untuk menentukan isolat yang digunakan pada pengujian in planta.

Bakteri simbiotik CMA diidentifikasi secara molekuler melalui teknik polymerase chain reaction (PCR) untuk target $16 \mathrm{~s}$ rRNA dan dilanjutkan dengan perunutan DNA (dilakukan di First Base, Malaysia). Primer yang digunakan ialah primer universal bakteri dengan primer forward $27 \mathrm{~F}$ (5'-TACGGYTACCTTGTTACGACTT-3') dan primer reverse $1492 \quad \mathrm{R}$ (5'-AGAGTTTGATCCTGGCTCAG-3').

Kitosan diperoleh dari Departemen Teknologi Hasil Perairan, Fakultas Perikanan dan Ilmu Kelautan IPB dalam bentuk serbuk. Sebanyak $0.7 \mathrm{~g}$ kitosan dicampurkan dengan $10 \mathrm{~mL}$ asam asetat $1 \%$ dan ditambahkan akuades sampai 1 L untuk menghasilkan larutan kitosan dengan konsentrasi $0.7 \%$.

Evaluasi Mekanisme Antagonisme in Vitro Agens Hayati terhadap B. theobromae

Evaluasi hiperparasitisme, antibiosis, produksi senyawa volatil dan enzim kitinase disusun dalam rancangan acak lengkap dengan 3 ulangan.

Hiperparasitisme. Khamir berumur 48 jam diinokulasikan di sekeliling medium AA blok berjarak $0.5 \mathrm{~cm}$ dari koloni $B$. theobromae. Inkubasi dilakukan selama 5 hari kemudian afinitas khamir diamati dengan menghitung jumlah sel khamir yang menempel pada hifa B. theobromae (Chan dan Tian 2005).

Antibiosis. Bakteri diinokulasikan pada bagian tengah medium TSA dan $B$. theobromae diinokulasi pada $2.5 \mathrm{~cm}$ sisi kanan dan kiri bakteri. Inkubasi dilakukan selama 2 hari. Tingkat hambatan relatif (THR) diukur menggunakan rumus sebagai berikut:

$$
\mathrm{THR}=\frac{\mathrm{R} 2-\mathrm{R} 1}{\mathrm{R} 1} \times 100 \%, \text { dengan }
$$

$\mathrm{R} 2$, jari-jari koloni $B$. theobromae yang menjauhi bakteri; R1, jari-jari koloni $B$. theobromae yang mendekati bakteri.

Produksi senyawa volatil. Isolat agens hayati diinokulasikan pada medium TSA pada dasar dan isolat $B$. theobromae diinokulasikan pada medium ADK bagian atas cawan. Inkubasi dilakukan pada suhu ruang selama 2 hari. Pengamatan dilakukan dengan membandingkan pertumbuhan antara B. theobromae pada perlakuan dan kontrol.

Produksi enzim kitinase. Koloni agens hayati diinokulasikan sebanyak $0.1 \mathrm{~mL}$ di atas kertas saring pada medium agar-agar koloidal kitin konsentrasi $0.4 \%$. Produksi enzim kitinase ditandai dengan pembentukan zona bening di sekitar koloni.

\section{Evaluasi Keefektifan Pengendalian in Planta}

Bibit jeruk kultivar Siam Pontianak berumur 3 bulan, hasil okulasi dari Balai Penelitian Tanaman Jeruk dan Buah Subtropik, Malang, ditanam pada pot berisi tanah steril dan pupuk kandang (1:1) sebanyak $5 \mathrm{~kg}$. Jeruk diberi perlakuan: (1) khamir $3.2 \times 10^{7} \mathrm{cfu} \mathrm{mL}^{-1}$ 1 minggu sebelum inokulasi patogen (MSbI), (2) CMA 4 MSbI, (3) bakteri simbiotik CMA $6.0 \times 10^{6} \mathrm{cfu} \mathrm{mL}^{-1} 1 \mathrm{MSbI}$, (4) kitosan $0.7 \%$ $2 \mathrm{MSbI}, 2$ dan 4 minggu setelah inokulasi (MSI), (5) khamir + CMA (6) CMA + kitosan, (7) khamir + kitosan, (8) khamir + CMA + kitosan, dan (9) kontrol. Setiap perlakuan diulang 3 kali dan masing-masing ulangan terdiri atas 3 unit tanaman.

Inokulasi buatan patogen dilakukan pada batang bawah jeruk, kulit batang jeruk dibilas dengan kloroks $0.5 \%$ kemudian dibilas dengan air steril. Biakan $B$. theobromae berumur 5 hari diinokulasikan pada $15 \mathrm{~cm}$ dari pangkal batang yang telah dilukai menggunakan jarum steril di 3 titik, lalu dibalut kapas steril basah.

Peubah pengamatan perkembangan penyakit meliputi: periode laten (PL), insidensi penyakit (IP), keparahan penyakit $(\mathrm{KP})$, laju infeksi (r), area under disease progress curve(AUDPC), tingkat asosiasi 
CMA, dan kandungan fenol total. Periode laten dihitung sejak inokulasi patogen sampai munculnya gejala. Insidensi penyakit dihitung menggunakan rumus:

$$
\mathrm{IP}=\frac{\mathrm{n}}{\mathrm{N}} \times 100 \% \text {, dengan }
$$

$\mathrm{n}$, jumlah tanaman yang terinfeksi; dan $\mathrm{N}$, jumlah tanaman yang diamati. Pengukuran keparahan penyakit menggunakan rumus:

$$
\mathrm{KP}=\frac{\sum_{i=1}^{k}\left(\mathrm{n}_{i} \times \mathrm{v}_{i}\right)}{\mathrm{Z} \times \mathrm{N}} \times 100, \text { dengan }
$$

ni, jumlah tanaman terinfeksi pada skor ke-i; vi, nilai skor ke-i; $\mathrm{N}$, jumlah tanaman yang diamati; dan $\mathrm{V}$, skor tertinggi yang terdapat pada acuan skoring (Tabel 1). Laju infeksi (r) dan AUDPC dihitung dengan persamaan:

$$
\begin{aligned}
& \mathrm{r}=\frac{\mathrm{e}}{\mathrm{t}}\left(\log \frac{1}{1-\mathrm{Xt}}-\log \frac{1}{1-\mathrm{X}_{0}}\right) \\
& \text { AUDPC }=\frac{(\mathrm{Xt}-\mathrm{Xo})}{2} \cdot(\mathrm{t}), \text { dengan }
\end{aligned}
$$

r, laju infeksi; e, nilai konstanta 2.3; t, selang waktu pengamatan; Xt, keparahan penyakit penyakit pada waktu-t; dan Xo, keparahan penyakit pada pengamatan sebelumnya. Pengamatan dilakukan pada 6-15 minggu setelah inokulasi (MSI).

Pengukuran tingkat asosiasi CMA dilakukan berdasarkan metode Brundrett
(1991) dengan teknik pewarnaan akar menggunakan zat biru tripan. Analisis kuantitatif total fenol dilakukan mengikuti metode Slinkard dan Singleton (1977) menggunakan pereaksi Folin-Ciocalteau yang diawali dengan ekstraksi etanol dari tanaman.

\section{Analisis Data}

Pengaruh perlakuan uji in vitro, perkembangan penyakit in planta, dan tingkat asosiasi CMA dianalisis ragam dan perlakuan yang berpengaruh nyata diuji lanjut dengan DMRT pada $\alpha 0.05$ menggunakan SAS 9.1.

\section{HASIL}

\section{Identifikasi Penyakit Busuk Batang pada Jeruk dan Bakteri Simbiotik CMA}

Hasil diagnosis penyakit busuk batang jeruk menunjukkan bahwa $B$. theobromae (BT Grt) memiliki karakter koloni aerial, hifa bersepta, berwarna putih sampai pada hari ketiga kemudian menjadi warna abu-abu kehitaman mulai hari keempat. Piknidium ditemukan pada medium AA setelah hari ke-24. Konidium $B$. theobromae memiliki satu sekat dengan dinding agak bergerigi. Konidium dapat diamati setelah hari ke-30 (Gambar 1).

Tabel 1 Skoring penyakit busuk batang jeruk berdasarkan luas gejala

\begin{tabular}{lcl}
\hline Skor & $\begin{array}{c}\text { Luas gejala } \\
\left(\mathrm{cm}^{2}\right)\end{array}$ & Keterangan \\
\hline 0 & 0 & Tidak terdapat gejala \\
1 & $0<\mathrm{x}<2$ & Muncul nekrotik pada batang \\
2 & $2 \leq \mathrm{x}<4$ & Mulai terbentuk gum \\
3 & $4 \leq \mathrm{x}<6$ & Gum melingkari setengah diameter batang, daun gugur \\
4 & $>6$ & Gum melingkari batang tanaman, tanaman mati meranggas \\
\hline
\end{tabular}

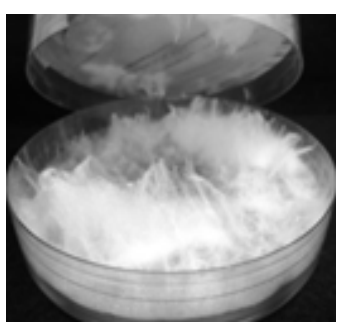

a

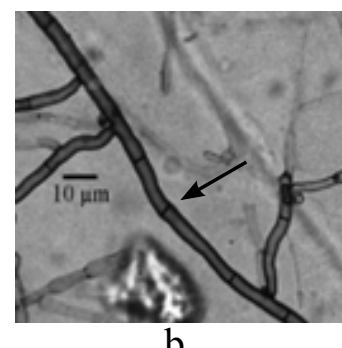

b

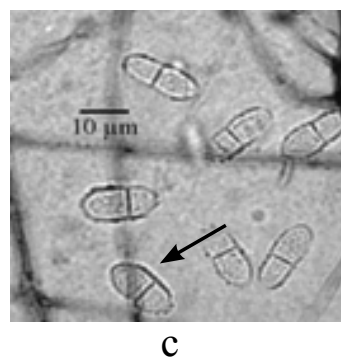

c

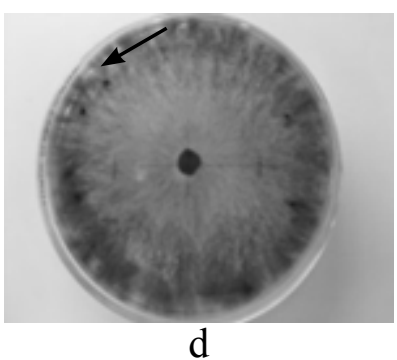

d

Gambar 1 Morfologi Botryodiplodia theobromae (BT Grt). a, Miselium aerial B. theobromae pada medium agar-agar dekstrosa kentang umur 4 HSI; b, Hifa bersepta; c, Konidium bersepta; d, Piknidium pada medium agar-agar air umur 24 hari. 
Tanaman jeruk yang diinokulasi buatan dengan $B$. theobromae menunjukkan gejala nekrosis, kulit batang terkelupas, muncul gum pada batang. Infeksi lanjut dari $B$. theobromae menunjukkan terhambatnya pembentukan daun baru, diikuti oleh penguningan daundaun tua, layu, dan tanaman mati meranggas secara keseluruhan (Gambar 2).

Berdasarkan karakter fisiologi dan hasil identifikasi secara molekuler, isolat bakteri simbiotik CMA (B2) terseleksi merupakan bakteri Gram positif, nonpatogen, dan memiliki homologi 98\% dengan Bacillus subtilis asal Vietnam (Gambar 3).

\section{Mekanisme Antagonisme in Vitro Agens Hayati terhadap $B$. theobromae}

Berdasarkan pengujian, khamir dan bakteri simbiotik CMA menunjukkan berbagai mekanisme dalam menghambat pertumbuhan dan perkembangan $B$. theobromae. Uji hiperparasitisme menunjukkan bahwa khamir memiliki afinitas 26 sel dan menyebabkan abnormalitas pada hifa $B$. theobromae

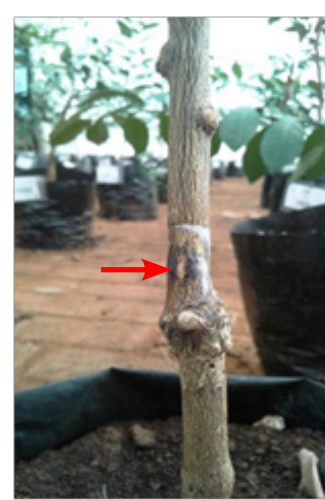

a

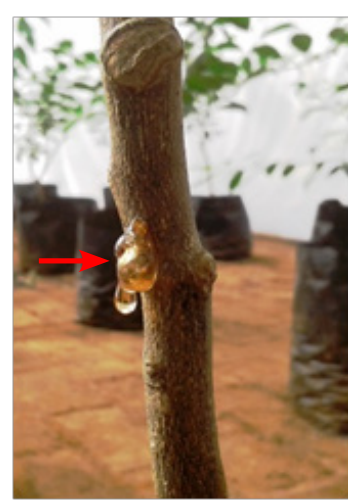

b

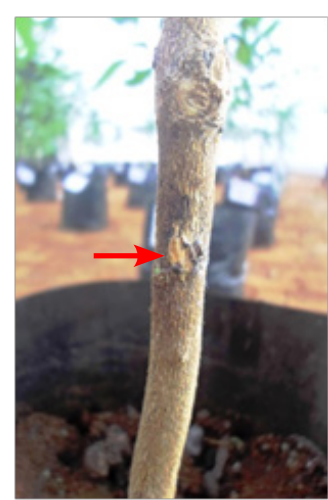

c

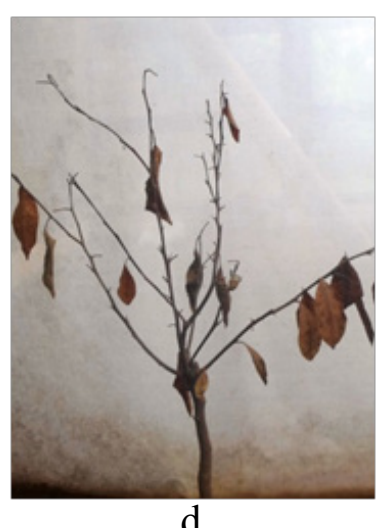

d

Gambar 2 Gejala infeksi Botryodiplodia theobromae pada batang tanaman jeruk. a, Nekrosis; b, Gumosis; c, Terkelupasnya kulit batang; d, Tanaman merangas.

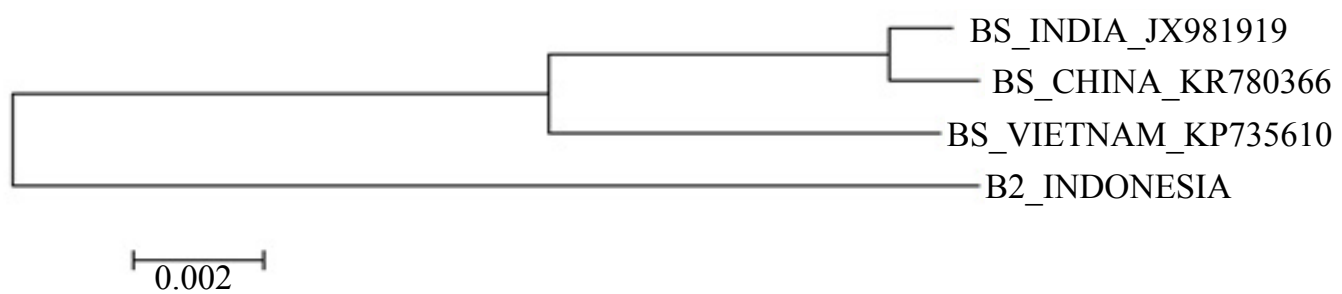

Gambar 3 Pohon filogenetika untuk isolat bakteri B2 dengan Bacillus subtilis asal Vietnam, Cina, dan India.

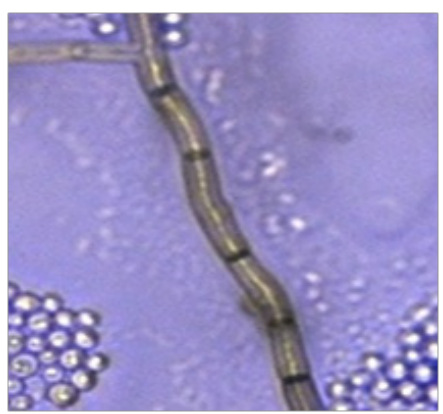

$\mathrm{a}$

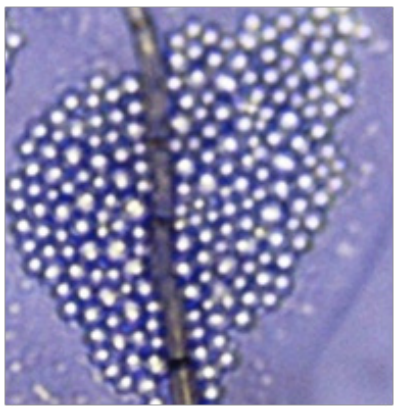

b

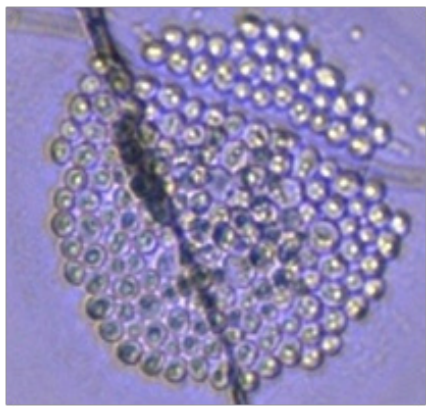

c

Gambar 4 Interaksi antara khamir (YP) dan Botryodiplodia theobromae (BT Grt) (perbesaran 400x). a, Hifa $B$. theobromae yang tidak terparasit; $b$, Sel-sel khamir mulai menempel pada hifa $B$. theobromae; c, Hifa B. theobromae abnormal setelah diparasiti oleh khamir. 
(Gambar 4). Uji antibiosis menunjukkan bahwa B. subtilis memiliki THR sebesar $42.9 \%$. Produksi senyawa volatil ditunjukkan dari THR 29.1\% (khamir) dan 26.7\% (B. subtilis). Khamir (YP) dan B. subtilis (B2) memproduksi enzim kitinase.

\section{Evaluasi Keefektifan Pengendalian in Planta}

Aplikasi agens hayati dan kitosan menunjukkan penekanan terhadap periode laten, insidensi, keparahan, laju infeksi, dan nilai AUDPC dari penyakit busuk batang. Rata-rata periode laten $B$. theobromae pada kontrol ialah 44.5 hari, sedangkan yang diberi perlakuan agens hayati dan kitosan berkisar 47.8-60.5 hari. Hal ini menunjukkan bahwa aplikasi agens hayati dan kitosan memperlambat periode laten. Perlakuan kombinasi khamir + CMA + kitosan secara nyata menurunkan insidensi penyakit, memperlambat laju infeksi dan nilai AUDPC (Tabel 2). Perkembangan penyakit seluruh perlakuan tunggal dan kombinasi selalu di bawah perkembangan penyakit pada kontrol. Perlakuan CMA tunggal dan khamir + CMA berhasil menekan keparahan penyakit pada akhir masa pengamatan (15 MSI) (Gambar 5). Perlakuan khamir + CMAmenunjukkan tingkat asosiasi CMA (39.1\%) dan kandungan fenol total tertinggi (300 $\left.\mathrm{mg} \mathrm{g}^{-1}\right)$. Perlakuan Khamir

Tabel 2 Periode laten, insidensi penyakit, keparahan penyakit, laju infeksi, dan nilai AUDPC busuk batang pada 15 minggu setelah inokulasi

\begin{tabular}{lccccc}
\hline Perlakuan & $\begin{array}{c}\text { PL } \\
\text { (hari) }\end{array}$ & $\begin{array}{c}\text { IP } \\
(\%)\end{array}$ & $\begin{array}{c}\text { KP } \\
(\%)\end{array}$ & $\begin{array}{c}\mathrm{r} \\
(\%)\end{array}$ & AUDPC \\
\hline Kontrol & $44.5 \mathrm{a}$ & $100.0 \mathrm{a}$ & $43.3 \mathrm{a}$ & $0.9 \mathrm{a}$ & $2210.8 \mathrm{a}$ \\
Khamir & $55.2 \mathrm{bc}$ & $80.0 \mathrm{ab}$ & $25.0 \mathrm{~cd}$ & $0.4 \mathrm{~b}$ & $1260.0 \mathrm{bc}$ \\
CMA & $53.4 \mathrm{bc}$ & $80.0 \mathrm{ab}$ & $18.3 \mathrm{~d}$ & $0.3 \mathrm{~b}$ & $898.3 \mathrm{c}$ \\
Kitosan & $55.6 \mathrm{bc}$ & $100.0 \mathrm{a}$ & $31.7 \mathrm{bc}$ & $0.5 \mathrm{~b}$ & $1575.0 \mathrm{~b}$ \\
Bacillus subtilis (B2) & $56.7 \mathrm{bc}$ & $73.3 \mathrm{ab}$ & $33.3 \mathrm{bc}$ & $0.6 \mathrm{~b}$ & $1662.5 \mathrm{ab}$ \\
Khamir + CMA & $47.8 \mathrm{ab}$ & $86.7 \mathrm{ab}$ & $23.3 \mathrm{~d}$ & $0.3 \mathrm{~b}$ & $1213.3 \mathrm{bc}$ \\
Kitosan + CMA & $48.2 \mathrm{ab}$ & $80.0 \mathrm{ab}$ & $26.7 \mathrm{~cd}$ & $0.5 \mathrm{~b}$ & $1370.8 \mathrm{bc}$ \\
Khamir + Kitosan & $55.2 \mathrm{bc}$ & $100.0 \mathrm{a}$ & $36.7 \mathrm{ab}$ & $0.8 \mathrm{ab}$ & $1639.2 \mathrm{~b}$ \\
Khamir + Kitosan + CMA & $60.5 \mathrm{c}$ & $66.7 \mathrm{~b}$ & $26.7 \mathrm{~cd}$ & $0.5 \mathrm{~b}$ & $1201.7 \mathrm{bc}$ \\
\hline
\end{tabular}

Angka dalam satu kolom yang diikuti huruf yang berbeda menunjukkan perbedaan nyata pada uji jarak berganda Duncan pada $\alpha 0.05$

PL: periode laten, IP: insidensi penyakit, KP: keparahan penyakit, r: laju infeksi, AUDPC: area under disease progress curve

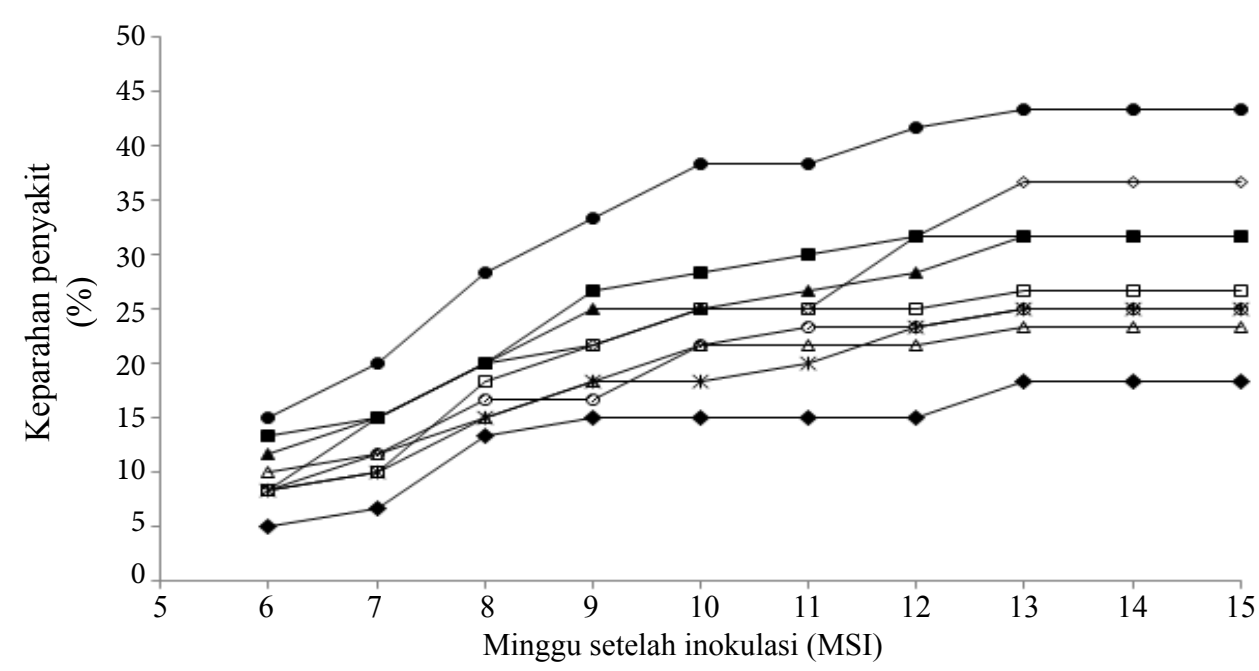

Gambar 5 Perkembangan keparahan penyakit busuk batang jeruk pada 6 sampai 15 MSI. $\rightarrow$, Kontrol; $\multimap-$, Khamir; $\multimap-$, CMA; $\bullet$, Kitosan; $\rightarrow-$, Bacillus subtilis; $₫$, Khamir + CMA; $\square$, Kitosan + CMA; $\rightarrow$, Khamir + Kitosan; $-*$, Khamir + CMA + Kitosan. 
Tabel 3 Tingkat asosiasi CMA dan perubahan kandungan fenol pada tanaman jeruk

\begin{tabular}{|c|c|c|c|}
\hline \multirow[t]{2}{*}{ Perlakuan } & \multicolumn{2}{|c|}{$\begin{array}{c}\text { Tingkat asosiasi CMA } \\
(\%)\end{array}$} & \multirow{2}{*}{$\begin{array}{l}\text { Kandungan fenol total } \\
\qquad\left(\mathrm{mg} \mathrm{g}^{-1}\right)\end{array}$} \\
\hline & Dengan patogen & Tanpa patogen & \\
\hline Kontrol & $0.0 \mathrm{~d}$ & $0.0 \mathrm{~d}$ & 120 \\
\hline Khamir & $0.0 \mathrm{~d}$ & $0.0 \mathrm{~d}$ & 110 \\
\hline CMA & $34.1 \mathrm{a}$ & $20.9 \mathrm{~b}$ & 120 \\
\hline Kitosan & $0.0 \mathrm{~d}$ & $0.0 \mathrm{~d}$ & 270 \\
\hline B. subtilis (B2) & $0.0 \mathrm{~d}$ & $0.0 \mathrm{~d}$ & 90 \\
\hline Khamir + CMA & $39.1 \mathrm{a}$ & $31.4 \mathrm{a}$ & 300 \\
\hline Kitosan + CMA & $5.2 \mathrm{c}$ & $5.2 \mathrm{c}$ & 0 \\
\hline Khamir + Kitosan & $0.0 \mathrm{~d}$ & $0.0 \mathrm{~d}$ & 150 \\
\hline Khamir + Kitosan + CMA & $18.3 \mathrm{c}$ & $7.8 \mathrm{c}$ & 130 \\
\hline
\end{tabular}

Angka dalam satu kolom yang diikuti huruf yang berbeda menunjukkan perbedaan nyata pada uji jarak berganda Duncan pada $\alpha 0.05$

dan B. subtilis menunjukkan kandungan fenol yang lebih rendah dari kontrol. Perlakuan kitosan + CMA menunjukkan tingkat asosiasi CMA yang rendah dan kandungan fenol pada perlakuan ini tidak terdeteksi (Tabel 3).

\section{PEMBAHASAN}

Penelitian ini menunjukkan bahwa masingmasing agens hayati dan kitosan memiliki mekanisme unggulan pada berbagai peubah pengamatan. Potensi unggulan khamir dalam pengendalian penyakit tanaman ialah produksi senyawa volatil dan enzim kitinase meskipun keefektifannya sangat bergantung pada jenis patogen dan jenis tanamannya. Sugipriatini (2009) melaporkan bahwa Cryptococcus albidus var. aerius IPB 1 berhasil menghambat pertumbuhan koloni $B$. theobromae pada mangga selama masa penyimpanan. Khamir Williopsis mrakii menghambat pertumbuhan B. theobromae sampai 100\% (Campos et al. 2010) melalui produksi senyawa volatil.

Meskipun menunjukkan aktivitas hiperparasitisme, produksi senyawa volatil dan produksi enzim kitinase oleh khamir pada uji in vitro tidak menekan perkembangan penyakit di lapangan jika diaplikasikan secara tunggal. Namun, kombinasi khamir + CMA mampu menekan perkembangan penyakit. Perlakuan khamir + CMA memiliki tingkat asosiasi CMA dan kandungan fenol total yang paling tinggi. Hal ini menunjukkan bahwa khamir memiliki interaksi sinergisme dengan CMA, sesuai dengan laporan Sampedro et al. (2004) yang menyatakan bahwa Rhodotorula mucilaginosa, Cryptococcus laurentii, dan Saccharomyces kunashirensis memproduksi eksudat yang dapat meningkatkan perkecambahan spora dan pertumbuhan hifa Glomus mussae. Hal ini akan meningkatkan peran CMA dalam melindungi tanaman dari cekaman biotik dan abiotik. Selain itu, tingginya tingkat asosiasi CMA juga akan meningkatkan kandungan fenol tanaman (Ozgonen et al. 2009).

Perlakuan tunggal CMA memiliki penekanan optimum terhadap perkembangan penyakit terutama pada akhir masa pengamatan. CMA dilaporkan dapat meningkatkan kemampuan tanaman dalam menyerap nutrisi, lignifikasi jaringan, dan produksi beberapa senyawa kimia seperti fenol, enzim kitinase, dan enzim $\beta-1,3$ glukanase (Ozgonen et al. 2009). Keberhasilan CMA dipengaruhi oleh populasi dan aktivitas $B$. subtilis yang menunjukkan aktivitas antibiosis, produksi senyawa volatil, dan produksi enzim kitinase in vitro meskipun percobaan aplikasi $B$. subtilis secara tunggal tidak menurunkan keparahan penyakit di lapangan. Bakteri simbiotik CMA diketahui berperan penting dalam peningkatan pertumbuhan hifa CMA dan kemampuan melarutkan fosfat.

Meskipun belum berhasil menekan perkembangan penyakit di lapangan, perlakuan kitosan menunjukkan kandungan fenol total 
yang tinggi. Menurut Hadrami et al. (2010), tingginya produksi senyawa fenol pada tanaman dipicu oleh aplikasi kitosan yang merupakan respons dari produksi enzim hidrolitik oleh cendawan patogen. Bersamaan dengan produksi senyawa fenol, enzim $\beta-1,3$ glukanase juga diproduksi sebagai pertahanan mekanis terhadap invasi miselium cendawan dan melindungi jaringan tanaman dari senyawa yang bersifat fitotoksik yang dikeluarkan oleh cendawan patogen.

Berdasarkan hasil penelitian ini, perlakuan tunggal CMA menunjukkan penekanan yang optimum terhadap penyakit busuk batang. Hal ini didukung oleh asosiasi CMA dengan $B$. subtilis yang memiliki mekanisme antibiosis, produksi senyawa volatil, dan produksi enzim kitinase. CMA juga bersifat sinergis dengan khamir yang memiliki mekanisme hiperparasitisme, produksi senyawa volatil, dan produksi enzim kitinase. Oleh karena itu, perlakuan tunggal CMA dan kombinasi khamir + CMA direkomendasikan untuk pengendalian penyakit busuk batang jeruk.

\section{UCAPAN TERIMA KASIH}

Ucapan terima kasih disampaikan kepada Lembaga Pengelola Dana Pendidikan (LPDP), Kementerian Keuangan Republik Indonesia yang mendanai penelitian ini melalui Beasiswa Tesis 2016.

\section{DAFTAR PUSTAKA}

Adeniyi DO, Olufolaji DB, Joseph A. 2016. Characteristic variations in Lasiodiplodia theobromae; pathogen of inflorescens dieback of cashew in growing ecologies in Nigeria. Ann Res Rev Biol. 10(2):1-6. DOI: https://doi.org/10.9734/ ARRB/2016/18047.

Algam SAE, Xie G, Li B, Yu S, Lasen J. 2010. Effects of Paenibacillus strains and chitosan on plant growth promotion and control of ralstonia wilt in tomato. J Plant Pathol. 92(3):593-600.

Bakhtiar Y. 2013. Peran cendawan mikoriza arbuskular dan bakteri endosimbiotik mikoriza dalam meningkatkan daya adaptasi bibit kelapa sawit (Elais gunensis Jacq.) terhadap cekaman Ganoderma boninense Pat. Microbiol Indones. 6(4):157-164. DOI: https://doi. org/10.5454/mi.6.4.3.

Brundrett M. 1991. Mycorrhizas in natural ecosystems. Adv Ecol Res. 21:171-313. DOI: https://doi.org/10.1016/S00652504(08)60099-9.

Campos VP, de Pinho RSC, Freire ES. 2010. Volatiles produced by interacting microorganisms potentially useful for the control of plant pathogens. Ciência Agrotecnologia. 34(3):525-535. DOI: https://doi.org/10.1590/S 1413 70542010000300001.

Chan Z, Tian S. 2005. Interaction of antagonistic yeasts againts postharvest pathogens of apple fruit and possible mode of action. Postharvest Biol Tech. 36(2005):215-223. DOI: https://doi. org/10.1016/j.postharvbio.2005.01.001.

Hadrami AE, Adam LR, Hadrami IE, Daayf F. 2010. Chitosan in plant protection. Marine Drugs. 2010(8):968-987. DOI: https://doi. org/10.3390/md8040968.

Hartati S, Wiyono S, Hidayat SH, Sinaga MS. 2014.Seleksi khamir epifit sebagai agens antagonis antraknosa pada cabai. J Hort Indones. 24(3):258-265. DOI: https://doi. org/10.21082/jhort.v24n3.2014.p258-265.

Muhammad H, Armiati, Dewayanti W. 2003. Jeruk keprok selayar dan upaya pelestariannya. J Litbang Pertanian. 22(3):87-94.

Ozgonen H, Yardimci N, Kilic HC. 2009. Induction of phenolic compund and pathogenesis-related proteinbymychorrizal fungal inoculation against Phytophthora capsici Leonian in pepper. Pak J Biol Sci.12(17):1181-1187. DOI: https://doi. org/10.3923/pjbs.2009.1181.1187.

Salamiah, Badruzsaufari, Arsyad M. 2008. Jenis tanaman inang dan masa inkubasi patogen Botryodiplodia theobromae Pat. pada jeruk. JHPT Tropika. 8(2):123-131.

Sampedro I, Aranda E, Scervino JM, Fracchia S, Garcia-Romera I, Ocampo 
JA, Godeas A. 2004. Improvement by soil yeasts of arbuscular mycorrhizal of soybean colonized by Glomus mussae. Mycorrhiza. 14(4):229-234. DOI: https:// doi.org/10.1007/s00572-003-0285-y.

Sinaga MS, Wiyono S, Husni A, Kosmiatin M. 2009. Pemanfaatan batang bawah jeruk mutan dan mikoriza arbuskular untuk mengendalikan penyakit busuk pangkal batang pada tanaman jeruk. J Litbang Pertanian. 29(4):45-47.
Slinkard K, Singleton VL. 1977. Total phenol analysis: automation and comparison with manual methods. Am J Enololy Victicul. 28:49-55.

Sugipriatini D. 2009. Potensi penggunaan khamir dan kitosan untuk pengendalian busuk buah Lasiodiplodia theobromae (Pat.) Griffon \& Maubl. (syn. Botryodiplodia theobromae Pat.) pada buah mangga selama penyimpanan [tesis]. Bogor (ID): Institut Pertanian Bogor. 